\title{
PENGELOLAAN SUMBERDAYA UDANG YANG BERKELANJUTAN DI LAUT ARU DAN ARAFURA
}

\author{
Sustainable Management of Shrimp Resources in Aru and Arafura Sea \\ Oleh: \\ Mas Umamah ${ }^{1 *}$, Sugeng Hari Wisudo ${ }^{2}$, Ronny I Wahyu ${ }^{2}$ \\ ${ }^{1}$ Mahasiswa Program Studi Teknologi Perikanan Laut \\ ${ }^{2}$ Staf Pengajar Program Studi Teknologi Perikanan Laut \\ *Korespondensi: masumamah@yahoo.com
}

\begin{abstract}
ABSTRAK
Pemanfaatan sumberdaya ikan di Laut Aru dan Arafura sudah dilakukan sejak lama dengan menggunakan berbagai jenis armada penangkapan. Jenis tangkapan udang penaeid merupakan komoditas utama dari armada penangkapan yang beroperasi di perairan ini khususnya kapal trawl (pukat udang dan pukat ikan) karena merupakan komoditas ekspor utama yang bernilai tinggi. Upaya pengelolaan sumberdaya perikanan untuk menentukan tingkat pemanfaatannya agar dapat dilakukan secara berkelanjutan telah dilakukan pemerintah antara lain melalui Peraturan Menteri Kelautan dan Perikanan (PERMEN KP) No. 56/PERMEN-KP/2014 Tentang Penghentian Sementara (Moratorium) Perizinan Usaha Perikanan Tangkap di WPPNRI dan PERMEN KP No. 2/PERMEN-KP/2015 Tentang Larangan Penggunaan Alat Penangkapan Ikan Pukat Hela (Trawls) dan Pukat Tarik (Seine Nets) di WPPNRI. Penelitian bertujuan untuk menghitung dan menganalisis tingkat produktivitas kapal pukat udang, menghitung dan mengestimasi jumlah hari operasi penangkapan dan jumlah kapal yang ideal untuk pemanfaatan sumberdaya udang di Laut Aru dan Arafura. Penelitian dilakukan terhadap kapal pukat udang yang beroperasi dari tahun 2002-2015. Perhitungan hasil tangkapan pada kondisi maksimum lestari dan upaya penangkapan dianalisis dengan metode surplus model yang dikembangkan oleh Wiranata (2016). Hasil penelitian menunjukkan estimasi hasil tangkapan udang banana pada kondisi maksimum lestari ( $\left.Y_{\text {msy }}\right)$ sebesar 1.592,82 ton dengan upaya penangkapan optimum $\left(f_{\text {msy }}\right)$ sebesar 6.795 hari atau sebesar 26 unit kapal setara kapal pukat udang. Adapun hasil tangkapan aktual yaitu 839 ton dengan effort aktual sebesar 2.128 hari. Hal ini menunjukan bahwa pemanfaatan sumberdaya udang di Laut Aru dan Arafura dalam kondisi moderate atau belum mengalami tekanan eksploitasi yang berlebihan.
\end{abstract}

Kata kunci: laut aru dan arafura, maximum sustainable yield, pukat udang, sumberdaya udang, upaya penangkapan.

\section{ABSTRACT}

Fish resources utilization in Aru and Arafura Sea has been done for long time by various types of fishing fleet. Penaeid shrimp has being the main target of fishing fleet in these waters, especially trawlers (shrimp trawl and fish trawl), because as export commodity it has high value. Management efforts of fishery resources to determine utilization levels in purpose to sustainability have been conducted by the government, among others fishing regulation in Indonesia Fisheries Management Area by Ministrial Regulation No.56/PERMEN-KP/2014 about Moratorium of Fishing Lisence in Indonesia Fisheries Management Area, and Ministrial Regulation No.2/PERMEN-KP/2015 about Trawls and Seine Nets Ban. This study aimed to calculate and analyze the shrimp trawlers productivity, calculate and estimate the optimum number of days operations and number of fleets for shrimp resource utilization in Aru and Arafura Sea. Research had been conducted on shrimp trawlers which 
operating from year 2002 to 2015. Maximum sustainable yield ( $\left.Y_{\text {msy }}\right)$ estimation and fishing effort ( $\left.f_{\text {msy }}\right)$ were analyzed by surplus method model which developed by Wiranata (2016). The results shows that estimation of banana shrimp $Y_{m s y}$ in Aru and Arafura Sea amounted to 1,592.82 tonnes with optimum fishing effort $\left(f_{\text {msy }}\right)$ amounted 6,795 days or equal to 26 units of similar shrimp trawlers. The actual catch is amounted 839 tonnes with fishing effort amounted 2,128 days, it indicates that shrimp resources utilization in Aru and Arafura Sea is moderate.

Keywords: aru and arafura sea, maximum sustainable yield, shrimp trawl, shrimp resources, optimum effort.

\section{PENDAHULUAN}

Laut Aru dan Arafura merupakan bagian dari paparan sahul dengan kedalaman \pm 80 meter dan masuk dalam kategori perairan dangkal $( \pm 200 \mathrm{~m}$ ) dengan tingkat energi arus menengah sampai kuat serta kondisi dasar perairan sebagian besar berupa lumpur pasiran dengan sedikit lempung (Suhartati 2010). Pemanfaatan sumberdaya ikan di Laut Aru dan Arafura sudah dilakukan sejak lama dengan menggunakan berbagai jenis armada. Jenis tangkapan udang penaeid merupakan komoditas yang menjadi sasaran utama dari armada penangkapan yang beroperasi di perairan ini khususnya armada Trawl (pukat udang dan pukat ikan) karena merupakan komoditas ekspor utama yang bernilai tinggi. Berdasarkan data dari Pusat Data Statistik dan Informasi Kementerian Kelautan dan Perikanan (2015) disebutkan bahwa total volume ekspor hasil perikanan pada periode bulan Januari-Oktober 2015 sebesar 872 ribu ton dengan nilai sebesar US\$ 3,27 milyar dan kontribusi komoditas yang terbesar terhadap nilai ekspor tersebut adalah udang dengan nilai sebesar US\$1,37 milyar $(41,87 \%)$ kemudian disusul oleh komoditas tuna, tongkol, cakalang yaitu sebesar US\$ 492 juta $(15,03 \%)$ dan kepiting sebesar US\$ 266 juta $(8,12 \%)$.

Penelitian tentang potensi dan tingkat pemanfaatan sumberdaya udang di Laut Aru dan Arafura telah banyak dilakukan. Purwanto (2013) menyebutkan, hasil tangkapan lestari maksimum di Laut Aru dan Arafura pada tahun 2011 untuk perikanan udang sebanyak 49.500 ton pertahun sedangkan perikanan demersal sebanyak 539.100 ton pertahun. Upaya yang dilakukan dalam pemanfaatan sumberdaya tersebut dengan cara pemberian izin armada penangkapan ikan di Laut Aru dan Arafura. Pada tahun 2014, jumlah kapal yang beroperasi berdasarkan izin pusat yaitu kapal-kapal yang berukuran > 30 Gross Tonnage (GT) sejumlah 962 unit dengan urutan terbanyak pukat ikan yang berjumlah 366 unit sedangkan untuk pukat udang sebanyak 87 unit.

Pada tahun 2014 Kementerian Kelautan dan Perikanan melakukan penataan kegiatan penangkapan ikan di Wilayah Pengelolaan Perikanan Negara Republik Indonesia (WPPNRI) melalui Peraturan Menteri Kelautan dan Perikanan (PERMEN KP) No. 56/PERMEN-KP/2014 Tentang Penghentian Sementara (Moratorium) Perizinan Usaha Perikanan Tangkap di WPPNRI. Peraturan ini mengatur tentang penghentian sementara perizinan usaha perikanan tangkap di WPPNRI bagi kapal perikanan yang pembangunannya dilakukan di luar negeri (ex-asing). Kebijakan penataan kegiatan penangkapan ikan kemudian berberlanjut pada tahun 2015 dengan dikeluarkannya PERMEN KP No. 2/PERMEN-KP/2015 Tentang Larangan Penggunaan Alat Penangkapan Ikan Pukat Hela (Trawls) dan Pukat Tarik (Seine Nets) di WPPNRI dan dipertegas dengan PERMEN KP No. 71/PERMEN-KP/2016 Tentang Jalur Penangkapan Ikan dan Penempatan Alat Penangkapan Ikan di WPPNRI. Kebijakan ini berdampak pada seluruh kegiatan perikanan di wilayah WPPNRI termasuk di Laut Aru dan Arafura. Dampak yang timbul antara lain secara bertahap terjadi penurunan jumlah kapal perikanan yang beroperasi di Laut Aru dan Arafura yang awalnya berjumlah 962 unit pada tahun 2014 menjadi 481 unit pada tahun 2015 sehingga pemanfaatan sumberdaya udang di perairan tersebut secara bertahap menurun dan terhenti. 
Berdasarkan rekam data terakhir dari beberapa perusahaan yang masih mempunyai izin melakukan penangkapan didapat bahwa hasil tangkapan yang diperoleh meningkat secara tajam. Hal ini disebabkan berkurangnya jumlah armada yang beroperasi karena adanya kebijakan tersebut. Dalam rangka upaya pemanfaatan dan pengelolaan perikanan udang tersebut, maka perlu strategi pengelolaan yang berkelanjutan antara lain melalui input control berupa pengaturan jumlah armada dan jumlah hari operasi penangkapan sehingga diharapkan hasilnya dapat digunakan sebagai salah satu bahan evaluasi penerapan dan pertimbangan kebijakan dimasa mendatang. Penelitian ini bertujuan untuk menganalisis dan menghitung Tingkat produktivitas pukat udang serta estimasi jumlah hari operasi penangkapan dan jumlah armada yang optimum untuk pemanfaatan sumberdaya udang di Laut Aru dan Arafura sehingga pemanfaatan sumberdaya udang dapat dilakukan secara optimal dan berkelanjutan (sustainable fisheries).

\section{METODE PENELITIAN}

Penelitian ini dilakukan terhadap kapal pukat udang yang beroperasi di Laut Aru dan Arafura dan mempunyai basis pendaratan di Sorong, Papua Barat. Data yang digunakan dalam analisis adalah data time series berupa data laporan (logbook) perusahaan pukat udang pada rentang waktu tahun 2002-2015. Pengambilan data dilakukan melalui survei, dan wawancara serta studi literatur. Wawancara dilakukan pada beberapa perusahaan yang mengoperasikan kapal pukat udang di Laut Aru dan Arafura. Data yang digunakan dalam penelitian ini terdiri dari data primer serta data sekunder yang diperoleh dari studi literature. Adapun jenis data yang digunakan antara lain: hasil tangkapan, jumlah trip penangkapan (hari), struktur armada penangkapan dan alat penangkapan ikan (jumlah dan jenis), serta potensi sumberdaya udang.

\section{Produktivitas Pukat Udang}

Tingkat produktivitas alat penangkapan ikan pukat udang dapat diduga dengan melihat hubungan antara hasil tangkapan (catch) dengan upaya penangkapan (effort) yang disebut catch per unit effort (CPUE). CPUE ini merupakan salah satu indikator dari status sumberdaya ikan, sehingga gambaran tentang trend CPUE dari suatu perikanan merupakan salah satu indikator sehatnya suatu perikanan (Badrudin 2012). CPUE alat tangkap pukat udang dapat dihitung dengan menggunakan rumus:

$$
\text { CPUE }=\frac{C_{t}}{E_{t}}
$$

Keterangan:

CPUE : Catch per unit effort

Ct : Hasil tangkapan pada tahun ke-t

$\mathrm{E}_{\mathrm{t}} \quad$ : Upaya penangkapan pada tahun ke-t

\section{Pendugaan Potensi Lestari}

Perhitungan hasil tangkapan maksimum lestari (Maximum Sustainable Yield) dan upaya tangkapan yang dilakukan pada saat perolehan maksimum lestari (Optimum Effort) suatu unit penangkapan pukat udang dapat dihitung dengan menggunakan metode surplus model yang dikembangkan Wiranata (2016) melalui persamaan kuadratik:

$$
\mathrm{Y}=a f-b f^{2}
$$

Nilai maksimum dari upaya penangkapan $\left(f_{m s y}\right)$ :

$$
f_{m s y}=\frac{a}{2 b}
$$

Nilai tangkapan maksimum lestari $\left(Y_{m s y}\right)$ : 


$$
Y_{m s y}=\frac{a^{2}}{4 b}
$$

\section{HASIL DAN PEMBAHASAN}

\section{Produksi Sumberdaya Ikan di Laut Aru dan Arafura}

Produksi perikanan tangkap Indonesia tahun 2015 menurut statistik perikanan tangkap tercatat sebanyak 6.204.668 ton. Dari data tersebut jumlah produksi yang tertangkap di WPPNRI 718 sebanyak 413.118 ton atau hampir 3.6\% dari total produksi yang dihasilkan. Data statistik juga menyebutkan total produksi perikanan tangkap di WPPNRI 718 pada tahun 2014-2015 mengalami penurunan sebesar 40.79\% yaitu dari 413.119 ton menjadi 244.590 ton. Penurunan produksi ini berkorelasi dengan adanya kebijakan penataan kegiatan penangkapan ikan yang dilakukan oleh pemerintah.

1. Ikan pelagis besar

Produksi ikan pelagis besar di WPPNRI 718 selama 10 tahun mengalami fluktuasi kenaikan ratarata sebesar $10.06 \%$. Fluktusi perkembangan produksi ikan pelagis besar dapat dilihat pada Gambar 3. Pada gambar tersebut dapat dilihat terjadi kecenderungan kenaikan dan penurunan produksi yang cukup signifikan pada tahun 2014 dan 2015. Total produksi pada tahun 2014 sebesar 117.761 ton dan turun drastis menjadi 36.133 ton pada tahun 2015. Tren kenaikan produksi ini dapat diduga karena adanya kebijakan moratorium kegiatan penangkapan di WPPNRI yang dilakukan sejak tahun 2014 dan komitmen tegas dari pemerintah dalam pemberantasan illegal fishing (penenggelaman kapal yang melakukan illegal fishing) sehingga tekanan kegiatan penangkapan ikan menurun. Armada penangkapan ikan yang dapat beroperasi hanya yang mempunyai izin dan masih berlaku sampai dengan masa berlakunya habis. Adapun fenomena penurunan produksi yang terjadi di tahun 2015 diduga merupakan dampak langsung dari kebijakan moratorium, dimana banyak armada penangkapan yang sebelumnya masa izinya masih berlaku telah habis sehingga armada yang beroperasi semakin sedikit.

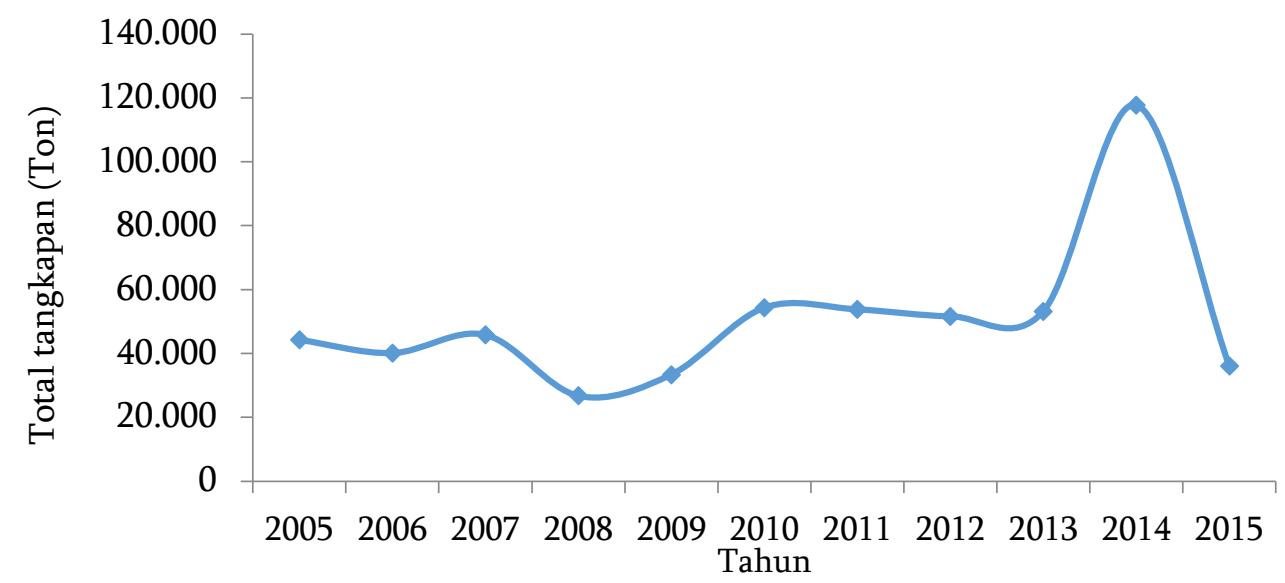

Gambar 1 Perkembangan produksi ikan pelagis besar tahun 2005-2015 berdasarkan statistik perikanan tangkap

2. Ikan pelagis kecil

Produksi ikan pelagis kecil di WPPNRI 718 selama 10 tahun mengalami fluktuasi penurunan rata-rata sebesar 2.20\%. Fluktusi perkembangan produksi ikan pelagis kecil dapat dilihat pada Gambar 4. Total produksi pada tahun 2015 hanya mencapai 48.679 ton. Tren penurunan ini diduga disebabkan oleh beberapa faktor. Tren penurunan produksi yang terjadi sebelum tahun 2014 disebabkan karena adanya praktek illegal fishing. Purwanto (2013) menyebutkan bahwa pada tahun 2011 stok udang yang ada di Laut Aru dan Arafura telah dimanfaatkan melebihi tingkat optimumnya (overfished) akibat 
tingginya intensitas operasi kapal perikanan tanpa izin (illegal fishing). Adapun tren penurunan produksi yang terjadi pada tahun setelah tahun 2014 di duga berkolerasi dengan kebijakan penataan kegiatan penangkapan ikan (moratorium penangkapan ikan). Jenis ikan pelagis kecil yang tertangkap antara lain adalah selar (Caranx spp.), layang (Decapterus ruselli), tetengkek (Megalaspis cordyla), ikan terbang (Cypselurus spp.), julung-julung (Hemirhampus spp.), kembung (Rastrelliger spp.), tembang (Sardinella fimbriata), belanak (Valamugil seheli) dan talang-talang (Scomberoides tol).

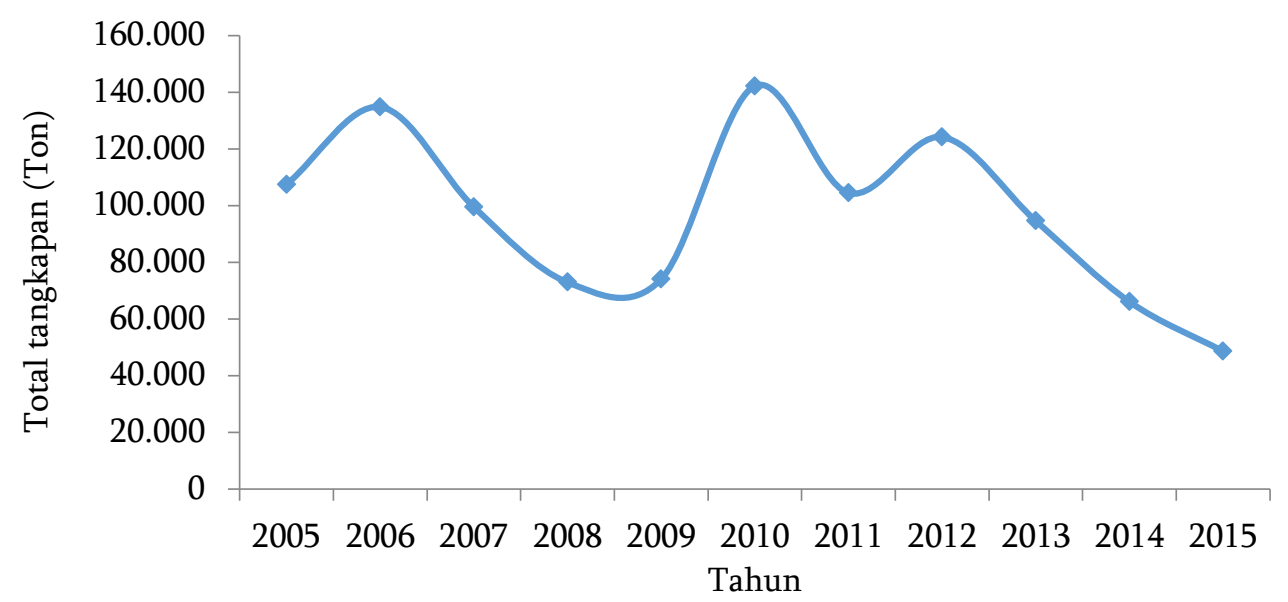

Gambar 2 Perkembangan produksi ikan pelagis kecil tahun 2005-2015 berdasarkan statistik perikanan tangkap

\section{Udang}

Udang merupakan sumberdaya yang dominan di WPPNRI 718. Nilai total produksi untuk sumberdaya ini dalam kurun waktu 10 tahun mengalami fluktuasi kenaikan rata-rata sebesar $26.37 \%$. Fluktusi perkembangan produksi udang dapat dilihat pada Gambar 7. Pada gambar tersebut dapat terlihat kenaikan produksi yang signifikan di tahun 2007. Menurut purwanto (2010) kenaikan produksi yang signifikan pada tahun 2007 ini disebabkan keberhasilan pengawasan dan penegakan hukum yang dilakukan oleh pemerintah sejak tahun 2000 yang menyebabkan menurunnya praktek illegal fishing sehingga upaya penangkapan juga mengalami penurunan. Dampak dari penurunan upaya penangkapan tersebut menyebabkan tingkat pemanfaatan udang diperairan ini pada tahun 2004 - 2005 tidak lagi berlebih sehingga terjadi pemulihan stok sumberdaya udang di tahun 2007. Jenis udang yang tertangkap di Perairan WPPNRI 718 antara lain adalah udang penaeid (udang dogol, udang jerbung, udang krosok, dll) serta lobster.

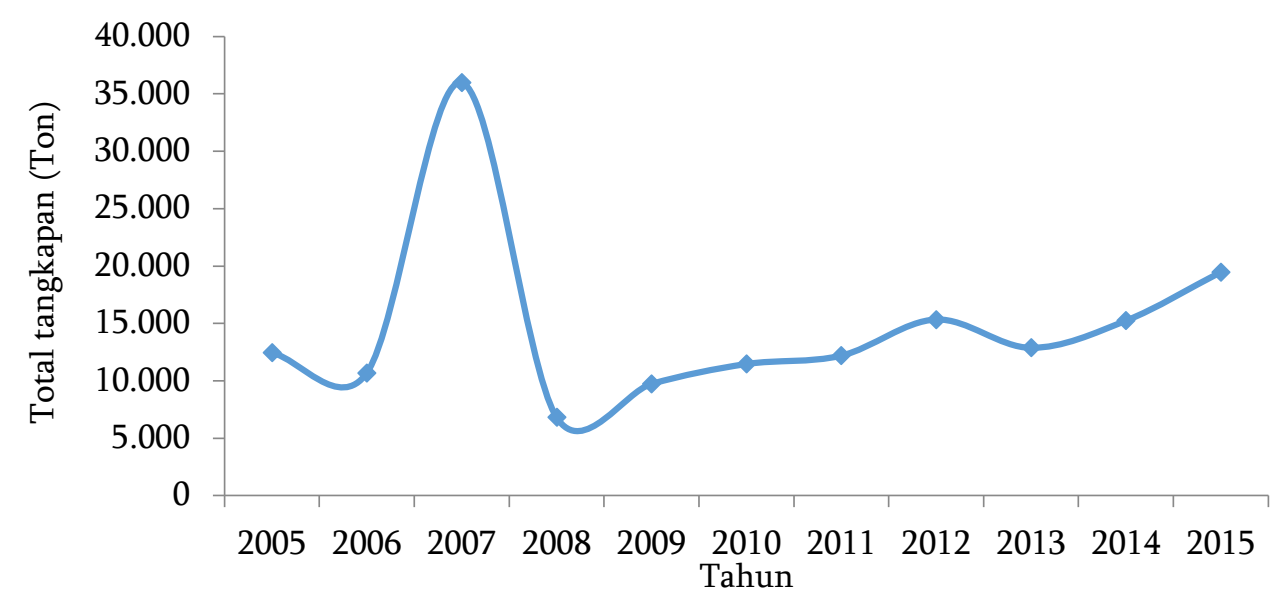

Gambar 3 Perkembangan produksi udang tahun 2005-2015 berdasarkan statistik perikanan tangkap 
Pemanfaatan sumberdaya ikan di laut Aru dan Arafura dilakukan melalui penangkapan dengan menggunakan berbagai jenis alat penangkapan ikan yang berdasarkan target sasaran (ikan pelagis besar, ikan pelagis kecil, ikan demersal dan udang). Empat jenis alat penangkapan ikan yang dominan beroperasi diperairan ini antara lain: pukat ikan, gillnet oseanik, squid jigging dan pukat udang.

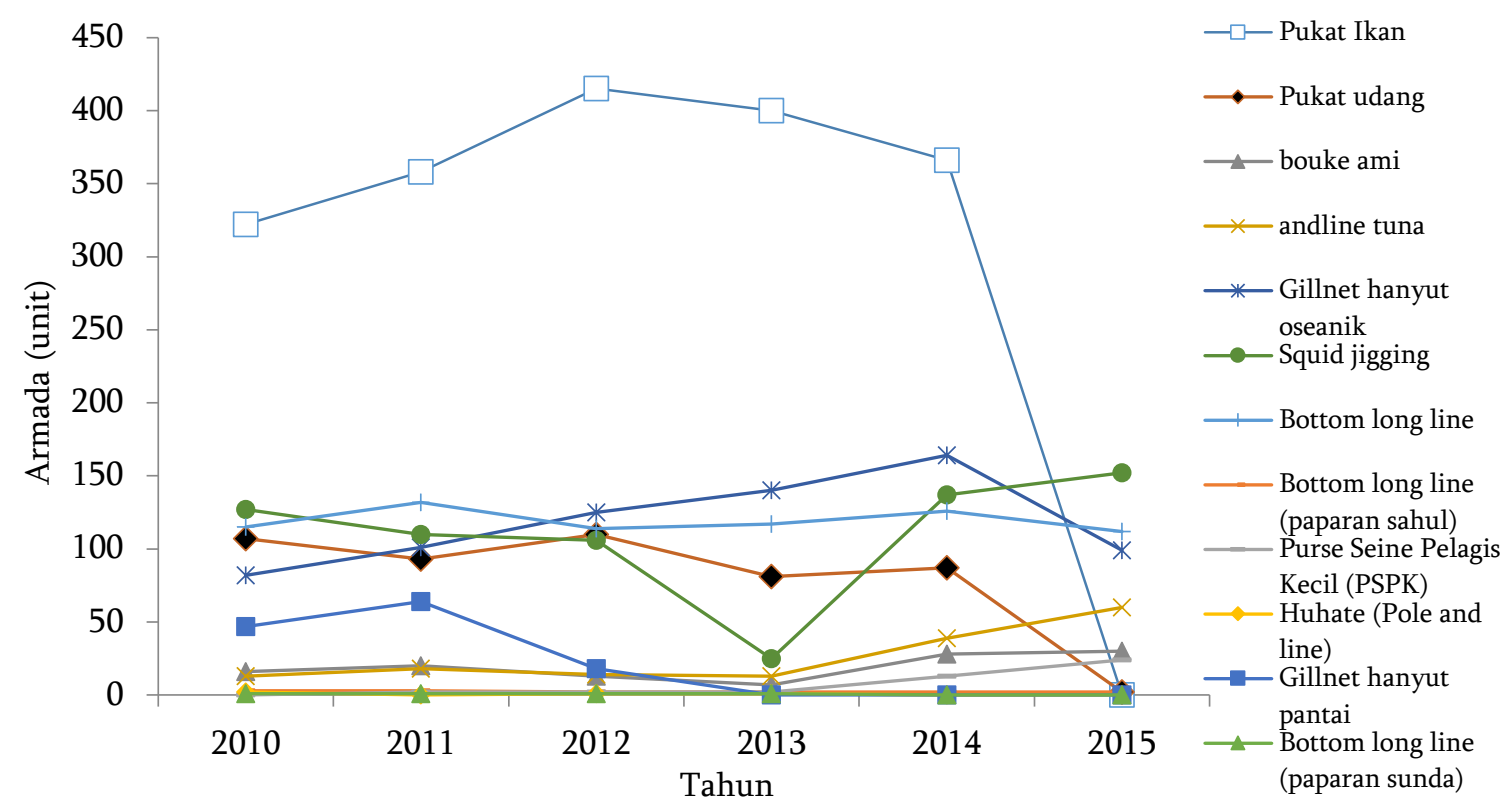

Gambar 4 Perkembangan alat penangkapan ikan yang beroperasi di Laut Aru dan Arafura

Berdasarkan data izin pusat yang dikeluarkan oleh Direktorat PUP pada tahun 2014 terdapat 962 unit alat penangkapan ikan yang beroperasi di perairan ini. Jumlah alat penangkapan ikan yang beroperasi dari tahun 2010 - 2015 dapat dilihat pada Gambar 8.

Gambar tersebut menunjukan terjadinya penurunan secara signifikan jumlah alat penangkapan ikan pada tahun 2015 yaitu dari 962 unit di tahun 2014 menjadi 481 unit pada tahun 2015. Unit penangkapan yang mengalami penurunan signifikan adalah pukat ikan dan pukat udang.

Penurunan unit penangkapan mulai terjadi pada tahun 2014 setelah berlakunya PERMEN KP No. 56/PERMEN-KP/2014 tentang Penghentian Sementara (Moratorium) Perizinan Usaha Perikanan Tangkap di WPPNRI. Peraturan ini mengatur tentang penghentian sementara perizinan usaha perikanan tangkap bagi kapal perikanan yang pembangunannya dilakukan di luar negeri (ex-asing). Data perizinan untuk kapal eks asing yang beroperasi di Laut Aru dan Arafura berjumlah 464 unit atau $\pm 48 \%$ dari total armada penangkapan yang beroperasi di perairan tersebut, sehingga dapat diduga penurunan unit penangkapan ikan yang terjadi merupakan dampak dari kebijakan tersebut. Penurunan unit alat penangkapan ikan kembali terjadi pada tahun 2015 bahkan secara signifikan. Fenomena ini diduga disebabkan pemberlakukan PERMEN KP No. 2/PERMEN-KP/2015 Tentang Larangan Penggunaan Alat Penangkapan Ikan Pukat Hela (Trawls) dan Pukat Tarik (Seine Nets) di WPPNRI sehingga kapal trawl (pukat ikan dan pukat udang) tidak dapat beroperasi di perairan Aru dan Arafura.

\section{Produktivitas Alat Penangkapal Ikan Pukat Udang}

Pukat udang yang beroperasi di Laut Aru dan Arafura menggunakan kapal yang berukuran antara $100 \mathrm{GT}$ - $250 \mathrm{GT}$. Beberapa kapal yang menjadi sampling penelitian, mempunyai fishing base di Sorong. Umumnya kapal tersebut terbuat dari besi dengan ukuran dimensi kapal: panjang $20-25 \mathrm{~m}$ dan lebar 6-8 m serta menggunakan mesin kapal yang berkekuatan $400-800$ PK. Jenis tangkapan udang penaeid merupakan komoditas yang menjadi sasaran utama dari armada penangkapan tersebut karena merupakan komoditas ekspor utama yang bernilai tinggi. Adapun jenis udang yang dominan 
tertangkap sesuai dengan daerah penangkapannya antara lain Banana (Penaeus merguiensis), Tiger (Penaeus japonicus), Black Tiger (Penaeus monodon) dan Krosok (Parapenaeopsis coramandelica).

Produksi hasil tangkapan udang banana dengan pukat udang di Laut Aru berfluktuatif dalam periode tahun 2002-2014 (Gambar 5). Dalam kurun waktu periode tersebut, hasil tangkapan terendah terjadi pada tahun 2002, yakni sebesar $553.424 \mathrm{~kg}$, namun dua tahun setelahnya (2003-2004) terus mengalami peningkatan hasil tangkapan dengan rata-rata kenaikan $41,22 \%$ per tahun. Tahun 2004 merupakan hasil tangkapan tertinggi sebesar $1.068 .610 \mathrm{~kg}$ atau naik $66 \%$ dari tahun sebelumnya (tahun 2003), namun tiga tahun (2005-2007) setelah tahun 2004 mengalami rata-rata penurunan sebesar $16,22 \%$ per tahun. Setelah tiga tahun mengalami penurunan, hasil tangkapan meningkat dari tahun sebelumnya (tahun 2007) sebesar 59\% di tahun 2008 dan tidak bertahan lama, lalu mengalami penurunan kembali selama dua tahun (2009-2010) dengan rata-rata penurunan sebesar 12,67\%. Penurunan hasil tangkapan tahun 2009-2010 dapat tertutupi dengan peningkatan yang terjadi pada tahun 2011 dan 2012 yang mengalami peningkatan sebesar 38\%. Tahun 2013 kembali mengalami penurunan hanya $16 \%$ dari tahun sebelumnya, lalu meningkat kembali di tahun selanjutnya sebesar $13 \%$.

Fluktuasi data hasil tangkapan udang banana dalam periode tahun 2002-2014 nilai rata-rata peningkatan hasil tangkapan masih paling besar daripada penurunannya, rata-rata peningkatannya mencapai $32,10 \%$ dan penurunannya sebesar $15,03 \%$. Berdasarkan hal tersebut diduga bahwa kecenderungan hasil tangkapan memiliki trend yang positif sesuai dengan rata-rata peningkatan yang lebih besar dari penurunannya.

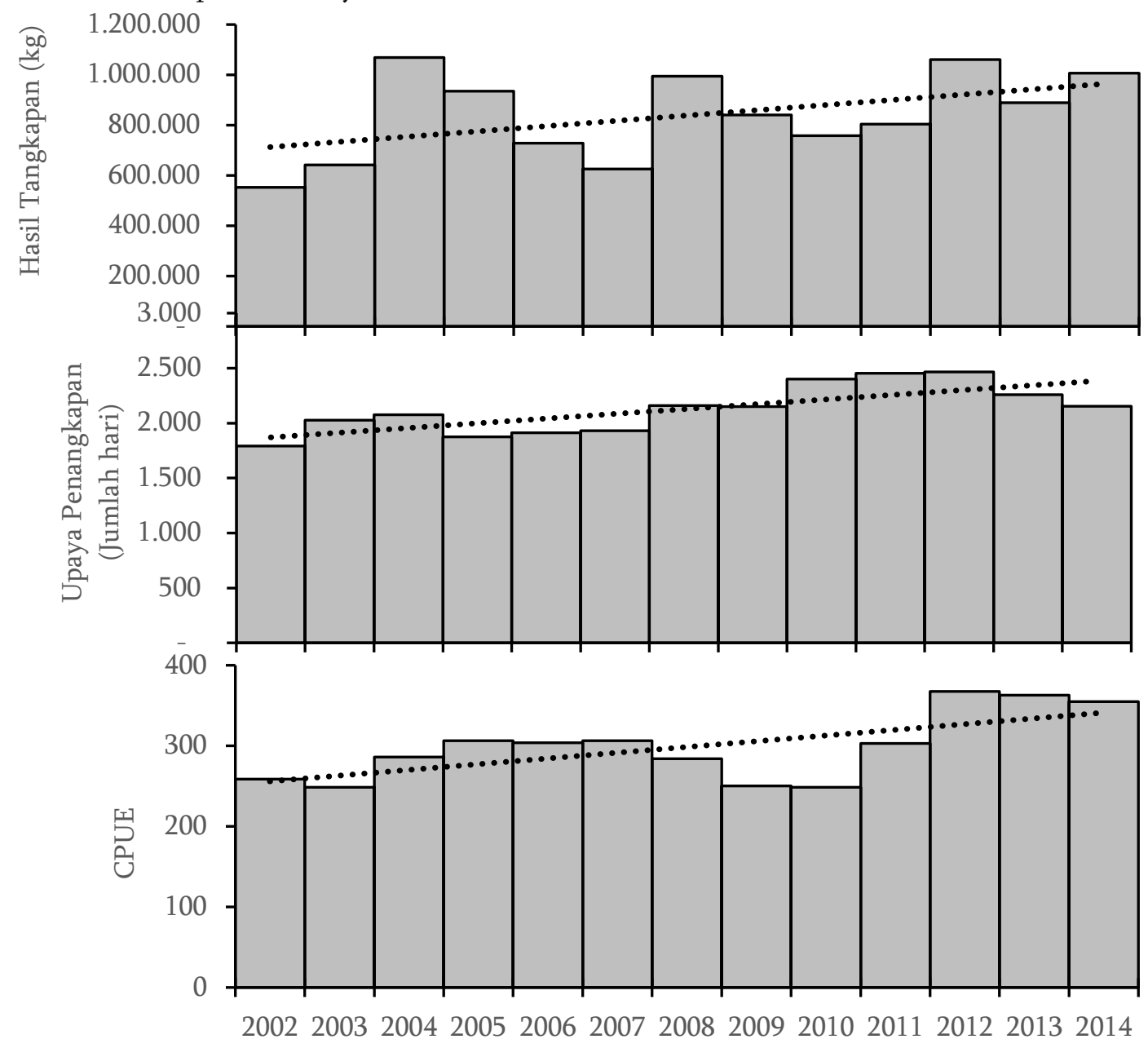

Gambar 5 Grafik perkembangan nilai hasil tangkapan (kg), upaya penangkapan (jumlah hari) dan CPUE udang banana 
Upaya penangkapan yang dilakukan untuk menangkap udang banana di Laut Aru tahun 20022014 juga berfluktuatif setiap tahunnya. Rata-rata upaya penangkapan tahun 2002-2014 sebesar 2.128 hari per tahun. Dalam rentang waktu tersebut, penurunan upaya penangkapan hanya terjadi empat kali, yaitu pada tahun 2005, 2009, 2013 dan 2014. Tahun 2005 merupakan penurunan yang paling besar yaitu mencapai 9,68\% dari tahun sebelumnya.

Fluktuasi data upaya penangkapan udang banana dalam periode tahun 2002-2014 nilai rata-rata peningkatan upaya penangkapan paling rendah daripada penurunannya, rata-rata peningkatannya mencapai 5,57\% dan penurunannya sebesar 5,77\%. Selisih antara peningkatan dan penurunnya hanya 0,2\% sehingga jika berdasarkan grafik dapat dikatakan setiap tahun jumlah kapal dan hari melaut meningkat dengan kecenderungan stabil.

Hasil tangkapan per upaya penangkapan atau catch per unit effort (CPUE) yang dilakukan untuk menangkap udang banana tahun 2002-2014 berfluktuasi karena jumlah effort dan hasil tangkapan juga berfluktuasi dari tahun ke tahun. Nilai CPUE ini mencerminkan produktivitas alat tangkap pukat udang yang digunakan untuk menangkap udang banana di Laut Aru. Dari grafik terlihat hasil tangkapan per upaya penangkapan udang banana di Laut Aru tahun 2002-2014 (Gambar 5).

Produktivitas alat tangkap pukat udang tertinggi terjadi pada tahun 2004 dan terendah pada tahun 2002. Pada tahun 2004 terlihat bahwa dengan upaya penangkapan yang sedikit mendapatkan hasil tangkapan yang cukup besar, sedangkan tahun 2002 upaya penangkapan yang cukup besar, hasil yang didapat relative kecil. Dengan demikian penggunaan pukat udang pada tahun 2004 bisa dikatakan lebih efisien jika dibandingkan dengan tahun 2002 karena nilai CPUE tahun 2004 lebih besar.

Menurut Cadima (2003) Nilai CPUE dapat mengindikasikan kelimpahan SDI dan besarnya produktivitas kapal perikanan yang diukur dengan hasil tangkapan per unit upaya penangkapan, sehingga dapat dikatakan bahwa trend kenaikan CPUE pukat udang di Laut Aru dan Arafura menandakan status sumberdaya udang relatif melimpah. Kenaikan CPUE ini terjadi diduga karena pemerintah dalam hal ini KKP telah melakukan pengaturan pengelolaan perikanan melalui kebijakan rasionalisasi pengurangan armada penangkapan (effort) secara bertahap dengan tidak memperpanjang izin penangkapan (moratorium) bagi seluruh kapal pukat hela (trawls) yang kemudian diperkuat dengan kebijakan pelarangan penggunaan alat penangkapan ikan trawl di seluruh WPPNRI sehingga berdampak positif terhadap kenaikan CPUE bagi kapal yang masih beroperasi sampai masa izinnya habis. Hasil penelitian ini sejalan dengan penelitian Purwanto (2010) yang menyatakan bahwa perbaikan pengelolaan perikanan yang dilakukan secara komprehensif melalui pengurangan jumlah armada penangkapan ikan yang melakukan kegiatan illegal fishing menyebabkan tingkat pemanfaatan stok udang di Laut Aru dan Arafura secara biologis tidak lagi berlebih sehingga berdampak positif terhadap pemulihan kelimpahan stok sumberdaya.

Nilai produktivitas pukat udang yang cenderung naik mengindikasikan adanya dampak dari kebijakan yang diambil pemerintah untuk mengelola sumberdaya melalui penghentian sementara (moratorium) kegiatan penangkapan ikan bagi kapal eks-asing dan kebijakan pelarangan penggunaan pukat hela dan pukat tarik.

\section{Produksi Lestari dan Effort Optimal}

Penentuan tangkapan maksimum lestari (Maximum Sustainable Yield) dan upaya penangkapan optimum (Optimum Effort) diperlukan pada suatu pengelolaan perikanan, dengan tujuan untuk menentukan tingkat pemanfaatan suatu sumberdayanya agar kelestarian sumberdaya tersebut dapat tetap terjaga. Hasil tangkapan maksimum juga merupakan salah satu titik acuan (reference point) dalam langkah pengelolaan (Nurhakim, 2004).

Koefisien fungsi produksi lestari (a dan b) tidak diestimasi melalui regresi linier biasa untuk menduga fungsi produksi lestari perikanan tangkap dengan persamaan $\mathrm{Y}=\mathrm{a} \mathrm{f}-\mathrm{b} \mathrm{f} 2$, namun dihitung secara langsung menggunakan metode yang pernah dilakukan oleh Wiranata (2016). Hasil tangkapan 
(kg) dinyatakan oleh $\mathrm{Y}$, sedangkan upaya penangkapan dinyatakan oleh $\mathrm{f}$ dalam satuan hari per tahun. Upaya penangkapan $\mathrm{f}$ berfungsi sebagai variable bebas (independent variable) dan hasil tangkapan berfungsi sebagai variable tidak bebas (dependent variabel).

Berdasarkan hasil perhitungan yang dilakukan, maka diperoleh nilai koefisien $\mathrm{a}=468,81 \mathrm{dan} \mathrm{b}$ $=0,0345$. Dengan demikian fungsi produksi udang banana di Laut Aru dapat ditulis $\mathrm{Y}=468,81 \mathrm{f}-$ $0,0345 \mathrm{f} 2$. Hasil perhitungan juga memperoleh nilai fmsy $=6.795$ hari. Nilai fmsy menunjukan jumlah hari operasi pukat udang yang dilakukan untuk mencapai tingkat hasil tangkapan maksimum lestari. Berdasarkan jumlah hari operasi optimum yang didapat apabila dikonversi ke unit kapal didapat 26 unit kapal yang setara dengan kapal pukat udang.

Perhitungan matematis hasil tangkapan pada kondisi maksimum lestari (Ymsy) diperoleh sebesar $1.592 .823 \mathrm{~kg}$ atau 1.592,82 ton per tahun. Nilai Ymsy menunjukan tingkat hasil tangkapan maksimum lestari yaitu hasil tangkapan berupa udang banana tertinggi yang dapat ditangkap tanpa mengancam kelestarian sumberdaya udang yang terdapat di Laut Aru. Hubungan kuadratik antara upaya penangkapan pukat udang dengan hasil tangkapan udang banana di Laut Aru dapat dilihat pada Gambar 6.

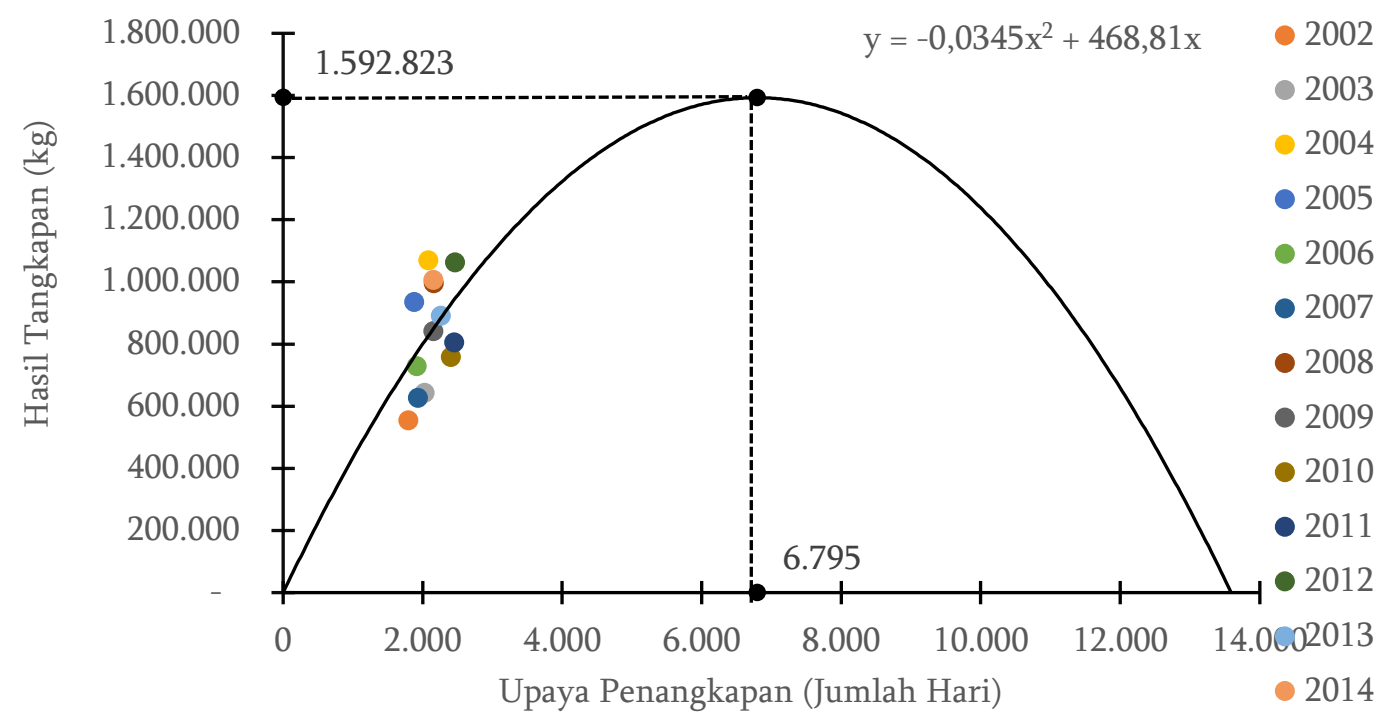

Gambar 6 Kurva hubungan hasil tangkapan (kg) dengan jumlah upaya penangkapan (jumlah hari) udang banana

Hubungan antara upaya penangkapan pukat udang dengan hasil tangkapan udang banana di Laut Aru berbentuk parabola (fungsi kuadratik). Artinya, setiap penambahan tingkat upaya penangkapan $\mathrm{f}$ akan meningkatkan hasil tangkapan $\mathrm{Y}$ hingga mencapai titik maksimum, kemudian akan terjadi penurunan hasil tangkapan untuk tiap peningkatan intensitas pengusahaan sumberdaya.

Hasil tangkapan maksimum lestari (Ymsy) dan upaya tangkapan optimum (fmsy) yang didapat jauh lebih kecil dari produksi aktual yang selama ini dihasilkan oleh perusahaan yaitu 839 ton/tahun dengan effort aktual sebesar 2.128 hari/tahun sedangkan hasil perhitungan Ymsy sebesar 1.592,82 ton/tahun dengan fmsy sebesar 6.795 hari/tahun, hal ini menunjukan bahwa tingkat pemanfaatan sumberdaya udang di Laut Aru dan Arafura masih dalam kondisi moderat atau belum mengalami tekanan eksploitasi yang berlebihan.

Berdasarkan tujuan pengelolaan perikanan menurut FAO (2009), secara umum terkait dengan 4 (empat) aspek yaitu 1) aspek biologis, 2) aspek ekologis, 3) aspek ekonomis dan 4) aspek sosial (politik dan budaya), maka didapatkan bahwa aspek biologis dan aspek ekologis perikanan pukat udang memberikan dampak negatif karena alat penangkapan ini sangat produktif dan tidak selektif, sehingga diperlukan upaya untuk pengelolaan lebih lanjut. 
Sularso (2005) menyatakan bahwa kebijakan pengelolaan sumberdaya di Laut Aru dan Arafura dilakukan melalui kebijakan jangka pendek dan jangka panjang. Kebijakan jangka pendek dilaksanakan dengan a). pengendalian upaya penangkapan dengan cara pengurangan jumlah kapal, b.) penerapan kuota penangkapan melalui pengurangan total hasil tangkapan; dan c). pemberlakukan open close season dengan melakukan penutupan area penangkapan pada waktu tertentu. Kebijakan jangka panjang dapat dilakukan melalui incentive adjusting instrumen yaitu seperti pengenaan pajak pada usaha perikanan.

Kebijakan moratorium penangkapan ikan dan pelarangan penggunaan alat penangkapan trawl dan seine net merupakan salah satu upaya pemerintah untuk mengatur kegiatan penangkapan ikan melalui input control dengan mempertimbangkan aspek-aspek tujuan pengelolaan. Hasil analisis menunjukkan dampak dari moratorium beberapa kapal pukat udang yang masih dapat beroperasi mengalami kenaikan produksi yang berdampak pada kenaikan produktivitas tiap kapal. Namun adanya upaya relokasi fishing ground bagi nelayan yang menggunakan alat penangkapan ikan selain trawl dan seine net untuk mengisi kekosongan kegiatan penangkapan di Aru dan Arafura perlu menjadi perhatian untuk rencana pengelolaan selanjutnya, hal ini untuk mencegah terjadinya kembali pemanfaatan sumberdaya secara berlebihan di wilayan perairan ini. Berdasarkan aspek-aspek yang ada, pengelolaan perikanan udang tetap harus dilakukan melalui pengaturan input control antara lain: a). pengaturan jumlah effort melalui pengaturan kapal, alat penangkapan atau pemilik/nelayan yang ikut dalam kegiatan penangkapan di satu lokasi fishing ground, b). pengaturan kapasitas perkapal dengan cara pembatasan ukuran kapal (GT) maupun kekuatan mesin kapal, c). Pengaturan jumlah hari operasi (trip) penangkapan dilaut, d). Pengaturan waktu penangkapan melaut seperti sistem open close season dan e). pengaturan lokasi penangkapan (fishing ground) seperti pemberian lokasi penangkapan tertentu kepada pengguna.

\section{KESIMPULAN DAN SARAN}

\section{Kesimpulan}

1. Produktivitas (CPUE) pukat udang di Laut Aru dan Arafura rata-rata sebesar $395 \mathrm{~kg} / \mathrm{tahun}$ dengan nilai tertinggi pada tahun 2004 sebesar $514.50 \mathrm{~kg} /$ tahun dan terendah pada tahun 2002 sebesar $308.66 \mathrm{~kg} /$ tahun;

2. Estimasi hasil tangkapan maksimum lestari (Ymsy) untuk udang banana sebesar 1.592,82 ton/tahun. Upaya penangkapan optimum untuk mencapai tingkat hasil tangkapan maksimum lestari dalam pemanfaatan sumberdaya udang di laut Aru dan Arafura (fmsy) adalah 6.795 hari;

3. Estimasi jumlah optimum kapal yang sesuai untuk pemanfaatan sumberdaya udang di Laut Aru dan Arafura adalah 26 unit kapal setara kapal pukat udang.

Saran

1. Perlu penyetaraan ke unit alat penangkapan lain sebagai pengganti trawl melalui perhitungan fishing power index (FPI);

2. Perlu penelitian lebih lanjut tentang alat penangkapan ikan yang ramah lingkungan dan legal pengganti pukat udang, apabila kebijakan pelarangan pukat hela (trawl) tetap berlaku.

\section{DAFTAR PUSTAKA}

Badrudin M. 2012. Analisis data catch dan effort untuk pendugaan MSY (Rapid Stock Assesment Tool) पmakalah $\square$. Jakarta (ID): Indonesian Marine and Climate Support (IMACS) Project. Kerjasama USAID dengan Kementerian Kelautan dan Perikanan.

Cadima EL. 2003. Fish stock assessment manual. Food Agriculture Organization Fisheries Technical Paper 393. Rome (IT): FAO. 161 p. 
[FAO] Food and Agriculture Organization of The United Nations. 2009. A Fishery Manager's Guidebook Second Edition. Rome (IT): FAO. 544 p.

Nurhakim S. 2004. Estimasi hasil tangkapan maksimum sumberdaya udang di laut arafura dengan model produksi surplus. Jurnal Penelitian Perikanan Indonesia. 10(5):85-93.

Purwanto. 2010. The biological optimal level of the Arafura shrimp fishery. Indonesian Fisheries Resources Journal. 16(2):79-89.

Purwanto. 2013. Produktivitas armada penangkapan dan potensi produksi perikanan udang di Laut Arafura. Jurnal Penelitian Perikanan Indonesia. 19(3):147-155.

Pusat Data, Statistik dan Informasi. 2015. Analisis Data Pokok Kelautan dan Perikanan. Pusat Data, Statistik dan Informasi. Jakarta (ID): Kementerian Kelautan dan Perikanan.

Suhartati MN, Rubiman. 2010. Distribusi foraminifera bentik resen di Laut Arafura. Jurnal Ilmu dan Teknologi Kelautan Tropis. 2(2):74-82.

Sularso A. 2005. Alternatif pengelolaan perikanan udang di Laut Arafura. [disertasi]. Bogor (ID): Institut Pertanian Bogor.

Wiranata AF. 2016. Status pemanfaatan perikanan tuna madidihang (Thunnus albacores) di Pelabuhan Perikanan Pantai Lombok [tesis]. Bogor (ID): Institut Pertanian Bogor. 